\title{
Geohydraulic and vulnerability assessment of tropically weathered and fractured gneissic aquifers using combined electrical resistivity and geostatistical methods
}

Adedibu Sunny AKINGBOYE ( $\nabla$ adedibu.akingboye@aaua.edu.ng )

Adekunle Ajasin University https://orcid.org/0000-0003-2195-6098

\section{Research Article}

Keywords: ERT, Schlumberger VES, geoelectrohydraulic method, regression analysis, groundwater vulnerability, gneissic aquifer

Posted Date: November 30th, 2021

DOI: https://doi.org/10.21203/rs.3.rs-1103032/v1

License: (c) (1) This work is licensed under a Creative Commons Attribution 4.0 International License. Read Full License 
1 Geohydraulic and vulnerability assessment of tropically weathered and fractured gneissic aquifers using combined electrical resistivity and geostatistical methods

4

\section{Adedibu Sunny Akingboye}

Department of Earth Sciences, Adekunle Ajasin University, 001 Akungba-Akoko, Ondo State, Nigeria Present Address: Geophysics Unit, School of Physics, Universiti Sains Malaysia, 11800 Pulau Pinang, Malaysia Corresponding author: adedibu.akingbove@aaua.edu.ng// https://orcid.org/0000-0003-2195-6098

\section{Abstract}

Sustainable potable groundwater supplied by aquifers depends on the protective capacity of the strata overlying the aquifer zones and their thicknesses, as well as the nature of the aquifers and the conduit systems. The poor overburden development of the Araromi area of AkungbaAkoko, in the crystalline basement of southwestern Nigeria, restricts most aquifers to shallow depths. Hence, there is a need to investigate the groundwater quality of the tropically weathered and fractured gneissic aquifers in the area. A combined electrical resistivity tomography (ERT) and Schlumberger vertical electrical sounding (VES) technique were employed to assess the groundwater-yielding potential and vulnerability of the aquifer units. The measured geoelectric parameters (i.e., resistivity and thickness values) at the respective VES surveyed stations were used to compute the geohydraulic parameters, such as aquifer resistivity $\left(\rho_{o}\right)$, hydraulic conductivity $(\mathrm{K})$, transmissivity $(\mathrm{T})$, porosity $(\varphi)$, permeability $(\Psi)$, hydraulic resistance $\left(\mathrm{K}_{R}\right)$, and longitudinal conductance (S). In addition, regression analysis was employed to establish the correlations between the $\mathrm{K}$ and other geohydraulic parameters to achieve the objectives of this study. The subsurface lithostratigraphic units of the studied site were delineated as the motley topsoil, weathered layers, partially weathered/fractured bedrock units, and the fresh bedrock, based on the ERT and the A, H, AK, HA, and KQ curve models. The K model regression-assisted analysis showed that the $\rho_{o}, \mathrm{~T}, \varphi, \Psi$, and $\mathrm{S}$ contributed about $81.7 \%$, $3.31 \% .96 .6 \%, 100 \%$, and $11.63 \%$, respectively, of the determined $\mathrm{K}$ values for the study area. The results, except $\mathrm{T}$ and $\mathrm{S}$, have strong high positive correlations with the $\mathrm{K}$ of the aquifer units; hence, accounted for the recorded high percentages. The aquifer units in the area were classified as low to moderate groundwater-yielding potential due to the thin overburden, with an average depth of $<4 \mathrm{~m}$. However, the deep-weathered and fractured aquifer zones with depths ranging from about 39-55 m could supply high groundwater yield for sustainable exploitation. The estimated $\mathrm{S}$ values, i.e., $0.0226-0.1926$ mho, for aquifer protective capacity ratings rated the aquifer units in the area as poor/weak to moderately high with extremely high to high aquifer vulnerability index, based on the estimated $\operatorname{low} \log \mathrm{K}_{R}$ of about $0.01-1.77$ years. Hence, intended wells/boreholes in the study area and its environs, as well as any environments with similar geohydraulic and vulnerability characteristics, should be properly constructed to adequately prevent surface and subsurface infiltrating contaminants.

Keywords: ERT; Schlumberger VES; geoelectrohydraulic method; regression analysis; groundwater vulnerability; gneissic aquifer 


\section{Introduction}

40 Globally, the percentage of people who use potable water has increased twice as fast as the global population $[1,2,3]$. Sustainable groundwater yield in aquifer zones depends on the detailed characterization of subsurface strata, the water-retaining capacity of the strata due to porosity and permeability, water-rock interactions, subsurface conduits, and storage zones, as well as the hydrodynamics of the aquifer units $[3,4-8]$. The sustainability of groundwater supplies also depends on the quality of the aquifers' yield, which is a function of the protective capacity of the strata overlying the aquifer zones and the depths of the aquifer zones. The occurrences of aquifer zones at shallow depths, especially within the crystalline basement terrain, give easy access for the percolation of surface runoffs and pollutants from dumpsites' leachate flows, surface and buried oil tank spillages, dissolved chemicals from mining activities, sewage from sanitation systems, etc., to degrade the stored groundwater [5, 9-12]. In addition, over-stretching of aquifers caused by over-abstraction of groundwater and silt/clay intrusion from improperly cased boreholes degrades the quality of groundwater [3, 13-15].

Geoelectrical resistivity methods, i.e., resistivity profiling and vertical electrical sounding (VES), and the estimation of geohydraulic parameters (e.g., hydraulic conductivity, transmissivity, porosity, permeability, transverse resistivity, longitudinal conductance, hydraulic conductance, etc.) from georesistivity datasets and/or pumping tests have been employed in the determination of groundwater-yielding potential and vulnerability of aquifer units in several geological terrains $[3,5,13,16,17]$. However, the pumping test method is time-consuming and expensive; hence, it has not often been utilized recently in geohydraulic evaluation since georesistivity methods are cost-efficient, rapid, and produce quality results with a higher success rate, e.g., $[3,10,11]$. The advantage of the georesistivity methods is that the measured resistivity values have strong correlations with groundwater hydraulic characteristics; hence, the data offer the determination of geohydrodynamics of aquifer units, protective capacity of the near-surface strata, and selection of suitable points for sustainable potable groundwater development $[5,10,11,18]$.

The study area covered a part of the Araromi area of Akungba-Akoko, southwestern Nigeria, which is situated between the main Akungba-Akoko town and Etioro-Akoko and is characterized by complex subsurface geology, e.g., [3, 8, 19-21]. The study area has become the choice location for many local settlers, staff, and students of Adekunle Ajasin University, 
71 previous workers in the study area and the surrounding towns, e.g., [3, 8, 19-21], the overburden in the areas is poorly developed and hence causes incessant water shortages to meet the growing population due to perennial failures of hand-dug wells and boreholes. In the report of Mohammed et al. [19], the groundwater potential of the northern section of the present study area was evaluated using the vertical electrical sounding (VES) technique. Akingboye et al. [8] investigated the near-surface crustal architecture and geohydrodynamics of the Araromi area, Akungba-Akoko (i.e., the study area) using the integrated coplanar loop electromagnetic conductivity method, electrical resistivity tomography (ERT), and Schlumberger VES technique, to ameliorate the difficulties of sufficient groundwater availability and the failure of engineering structural foundations in this area. Furthermore, the subsurface geological, hydrogeophysical, and engineering characterization, as well as the vulnerability of the southern part, (i.e., Etioro-Akoko), some few meters away, has been carried out and reported, e.g., [3, $8,21]$. From these studies, it was reported that most of the aquifer zones occurred at shallow depths, except for the localized ones that are characterized by deep-weathered troughs and fractures.

Despite the several detailed studies mentioned above, the vulnerability of the tropically weathered and fractured aquifer zones in the Araromi area of Akungba-Akoko has not been evaluated. Hence, it becomes necessary to determine the vulnerability of the aquifer zones to contamination due to the occurrence of most of the aquifers in the study area at shallow depths. The fracture densities and groundwater-yielding potential of some identified aquifers can also offer clues on the migration rate of possible contaminants in the area. Given the above, geoelectrohydraulic method, involving combined ERT and Schlumberger VES from which geohydraulic characteristics were determined through various equations and regressionassisted analysis to evaluate the vulnerability of the aquifer units in the study area.

\section{Geological setting of the study area}

Araromi area of Akungba-Akoko, which is the study site, falls between latitudes $07^{\circ} 27^{\prime} \mathrm{N}$ and $07^{\circ} 27^{\prime} 9^{\prime}$ ' $\mathrm{N}$, and longitudes $005^{\circ} 43^{\prime} 53^{\prime \prime}$ E and $005^{\circ} 44^{\prime} \mathrm{E}$ in the northern part of Ondo State, southwestern Nigeria, as shown in Figs. 1 and 2. The study area is characterized by the Nigerian rainforest belt climate, with average yearly rainfall between $1000 \mathrm{~mm}$ and $1500 \mathrm{~mm}$, and temperature is around $33{ }^{\circ} \mathrm{C}$. The area has a topographic relief consisting of hills, low-lying outcrops, plains, and valleys, between $280 \mathrm{~m}$ and $400 \mathrm{~m}$ above the mean sea level. The dendritic 
drainage system follows these topographic features, with trellis drainage patterns in a few places, e.g., $[3,8,21]$.

104 Geologically, the Araromi area of Akungba-Akoko is characterized by the Nigerian 105 Southwestern Precambrian Basement Complex, which is part of the reactivated Pan-African 106 mobile belt, occupying the east of the West African Craton and northwest of the Congo-Gabon 107 Craton [22-25], as shown in Fig. 1a. The Southwestern Basement Complex of Nigeria is made up of three major rock suites, namely the Migmatite-Gneiss Complex, ranging in age from Neoproterozoic to Paleoproterozoic and Archean, e.g., [22-24]; the Neoproterozoic Schist Belts, consisting of low-grade, younger metasedimentary, and metavolcanic rocks with ages ranging between 690 and 489 Ma, e.g., [23, 24], and the Pan-African Older Granites, which intruded the two earlier lithologies, have ages ranging between 650 and $580 \mathrm{Ma}$, e.g., [26, 27].

113 Early magmatic phases dating from 790 to 709 Ma have also been reported in some of the 114 Older Granites rocks. The Younger Granites, i.e., the Mesozoic anorogenic calc-alkaline ring complexes, as shown in Fig. 1b, intruded the Nigerian Eastern Basement Complex terrain before the formation of any of the sedimentary basins in the eastern and western terranes of Nigeria [26-28].

Figure 1. (a) Nigeria's regional geological map within the Pan-African mobile belt between the West African and Congo Cratons. (b) A detailed regional geological map of Nigeria showing the study area in the Nigerian Southwestern Basement Complex (modified after [28]). (c) Geological map of Akungba-Akoko and its surroundings in Ondo State, southwestern Nigeria (modified from [21]).

The entire Akungba-Akoko is underlain by the Migmatite-Gneiss Complex rocks of southwestern Nigeria, which were intruded by the Pan-African Granitoids as shown in Fig. 1c. The Migmatite-Gneiss Complex rocks in the area are typically migmatite, granite gneiss, and biotite gneiss, as well as granitoids consisting of charnockites and granites. Granite gneisses are the most abundant rock type in the area, and this particular rock underlies the Araromi part of the area. This particular rock type has a blastoporphyritic to porphyroblastic fabric and is light grey, medium to coarse-grained, and moderately foliated, for example (light and darkcolored bands). Far to the west, the rock is extensively deformed and migmatized, forming migmatite with an ENE-WSW trend. In addition, important intrusives in the granite gneisses 
in the area include quartz veins, pegmatite, aplite, basic dykes, and sills $[3,8,23,29]$. The tropical climatic conditions combined with the metamorphic activities in the Akungba-Akoko Basement Complex terrain have assisted in the weathering and fracturing of the subsurface strata.

The subsurface hydrogeological features of the Araromi area of Akungba-Akoko are similar to those of the surrounding towns, e.g., the main Akungba-Akoko town and Etioro-Akoko community, e.g., [3, 19-21], as well as some places in the crystalline basement of southwestern Nigeria, e.g., $[11,12,30]$. The groundwater in the study area occurs in weathered and/or fractured aquifer zones. Groundwater occurrence in these hydrogeologic units is unevenly distributed, just like other parts of the Precambrian basement terrain. Generally, the aquifers in the area are characterized by shallow depths with low porosity and permeability, and hence depend on the secondary porosity resulting from deep weathering and fracturing of the rock units to conduit and store fluids in the subsurface strata sufficiently. It has been reported that the aquifer zones in the study area and surrounding communities have an average depth of about $12 \mathrm{~m}$, with depths exceeding $25 \mathrm{~m}$ for deeply weathered and fractured aquifers, e.g., [3, $8,21]$. Some of the hand-dug wells and boreholes sited in the study area take advantage of the former and latter aquifer depths, respectively, for the required groundwater supplies.

\section{Methods of Study}

Due to the urgent need of the inhabitants of the Araromi area for steady and sufficient drinkable groundwater supplies to suit their everyday activities, a detailed subsurface geologic condition is highly necessary. The field data collection began with the identification of prominent areas with records of failed hand-dug wells and low yield boreholes in the study area. Predictions from earlier studies in the northern and southern areas of the study region, such as $[3,8,19$, 21], enabled the selection of locations for establishing the geophysical traverses for data collection quicker and simpler. Six traverses (TRs) were occupied in the study area as shown in Figs. 2a and b, to investigate and characterize the subsurface stratigraphic units, hydrodynamics, degree of weathering, and fracture densities. The implications of these characteristic features on the groundwater potentials and vulnerability of aquifers to contamination were also evaluated from geoelectrohydraulic and statistical methods. TRs 1-3 and TRs 4-6 were established in the NNE-SSW and NW-SE directions, respectively. TRs 1, 2 , and 6 each have a survey profile length of $160 \mathrm{~m}$, but TR3 has a survey profile length of just $100 \mathrm{~m}$ due to survey spread constraints. The survey spread length for TR4 is $150 \mathrm{~m}$, although 
the ERT profile was terminated at a distance of $145 \mathrm{~m}$ from the starting electrode. As shown in Figs. 2a and b, the TR5 survey spread length was $110 \mathrm{~m}$. Because of the population increase, structural building blockage caused a reduction in geophysical survey spread lengths on some traverses.

Figure 2. (a) Aerial map showing the data acquisition and all the geophysical traverses, (b) elevation map showing all the VES survey station points and existing hand-dug wells in the study area, and (c) the 3-D topographical view of the study area.

The ABEM Resistivity Imaging System was used for the ERT field data acquisition, utilizing the dipole-dipole electrode configuration protocol array because of its high sensitivity to vertical and lateral subsurface structural variations and low electromagnetic coupling effects, e.g., $[8,31,32]$. A station interval of $5 \mathrm{~m}$ was used for the detailed subsurface imaging of the anomalous features of interest for this study. Although the adopted $n$-level of 5, i.e., $(n=5)$, for dipole-dipole resistivity surveys could limit the depths of probing. However, the station interval is considered suitable to derive more cluster near-surface information and to avoid nuisance surface artifacts arising from the complex geological condition of the study area terrain. The Schlumberger electrode configuration for the VES technique, on the other hand, was carried out at the selected conductive or relatively conductive survey station points to address depth limitations. The approach was aimed at constraining the modeled ERT results, and to image deep-weathered bodies and the penetrative fractures. Figure $2 b$ depicts the spatial distribution of the investigated VES station sites, whereas Figs. $2 b$ and $2 c$ depict the elevation of the surface topography. The current electrodes $\mathrm{AB} / 2$ varied from 60 to $160 \mathrm{~m}$, whereas the potential electrodes spread $\mathrm{MN}$ were varied from 0.5 to $15 \mathrm{~m}$. The depth of penetration in a homogenous subsurface geologic structure is proportional to the distance between the current electrodes, whereas, varying the electrodes distance offers information regarding the subsurface lithostratigraphic units, e.g., $[3,8,12]$. When a remarkable resistivity of fresh bedrock, typically with values $>1200 \Omega \mathrm{m}$, was attained more than twice at each VES station, the survey was stopped, indicating that there was no possibility of obtaining a fracture at deeper depths even for further probing. However, because of the barriers encountered due to primarily buildings, the surveys were sometimes halted before reaching depth to the fresh basement. 
The results from the ERT surveys were processed and inverted using RES2DINV software. Forward modeling and data inversion, utilizing the least-squares inversion approach, which depends on a mathematical inverse problem to derive the subsurface resistivity distribution from apparent resistivity data sets, were used in the inversion process. Many works have reported on the adopted inversion processes used in the RES2D data inversion, including Akingboye et al. [8], Loke [31], DeGroot-Hedlin \& Constable [33], Dahlin \& Loke [34], Akingboye \& Bery $[14,35]$, and other. The ERT field data sets with topography were inverted using the finite-element method of 4 nodes with $\mathrm{L}_{2}$-norm as the least-squares constraint parameter to minimize the difference between the measured and calculated apparent resistivities. A damping factor of 0.05 with a minimum value of 0.01 was employed to increase the accuracy of the calculated apparent resistivities and the resolution of the generated apparent resistivities. The root-mean-square (RMS) error limit for inverse model convergence was set to less than $10 \%$ for a maximum of 7 iterations. The desired cut-off error was set at $40 \%$ with a maximum error of $200 \%$ to achieve the desired results. Figure 3 shows the composite ERT inversion results, which include measured and calculated pseudosections as well as inverted resistivity sections for the analyzed TR1. The VES field results were successively inverted using the IPI2win software to curve match the field data to generate the model resistivity curve, which included the thicknesses and depths of the geoelectric layers, as well as the resistivity values of the delineated layers. High anomalous peaks in a curve compared to the surrounding stations were reduced in comparison to the surrounding data, owing to poor electrode grounding, circuit relay, or current transmission issues due to dry ground. Following these corrections, the iteration of such VES field data was repeated. The RMS error of the iteration convergence limit was set at less than $10 \%$. The results were used to compute the geohydraulic characteristics of aquifer zones in the studied area. Other software, involving Oasis Montaj ${ }^{\mathrm{TM}}$ and Geosoft Surfer ${ }^{\mathrm{TM}}$, was used to produce two-and three-dimensional (2-D and 3-D) maps for this study.

Figure 3. Composite results of the 2-D ERT inversion beneath TR1.

The hydraulic conductivity $(\mathrm{K})$ and transmissivity $(\mathrm{T})$ of the aquifers, expressed in $\mathrm{m} /$ day and $\mathrm{m}^{2} /$ day, were computed using Equations 1 and 2 given by Heigold et al. [36] and Niwas \& Singhal [37], respectively. Transmissivity gives the areal extent of pore-water flow per day in the saturated hydrogeologic units. In addition to these parameters, the porosity $(\varphi)$ and permeability $(\Psi)$ of the hydrogeologic units at each VES point were also computed using 
227 Equations 3 and 4, respectively. The longitudinal conductance (S) of the overburden at each 228 VES station point was also estimated using Equation 5, as suggested by [38, 39]. The hydraulic resistance $\left(\mathrm{K}_{R}\right)$, expressed in years, was estimated to ascertain the AVI of the hydrogeologic unit in the studied site using Equation 7 given by Van Stempvoort et al. [40]. The logarithm of the hydraulic resistance, i.e., $\log \mathrm{K}_{R}$, was estimated to measure the AVI of the APC of the overburden unit to the vertical flow of fluid.

233

Where $\rho_{0}$ is the resistivity $(\Omega \mathrm{m})$ of the aquifer, $\sigma, S$, and h are the conductivity, longitudinal conductance (mho), and the thickness (m) of the aquifer, respectively. $v_{d}, \partial_{w}$, and $g$ are the water dynamic viscosity adopted as $0.0014 \mathrm{~kg} / \mathrm{m} / \mathrm{s}$ according to Fetters [41], the density of water $\left(1000 \mathrm{~kg} / \mathrm{m}^{3}\right)$, and acceleration due to gravity, respectively. $\rho_{i}$ and $h_{i}$ are the resistivity and thickness of the $i^{\text {th }}$ layer, respectively.

244 To further substantiate the analyses of the geohydraulic parameters for the Araromi area of 245 Akungba-Akoko, regression analysis was performed using geohydraulic conductivity (K), as 246 the independent variable, to predict the values of the dependent variables, i.e., transmissivity $247(\mathrm{~T})$, porosity $(\varphi)$, permeability $(\Psi)$, transverse resistance $\left(T_{R}\right)$, longitudinal conductance $(\mathrm{S})$, and hydraulic resistance $\left(\mathrm{K}_{R}\right)$, as well as aquifer resistivity $\left(\rho_{o}\right)$. These geostatistical analyses illuminate the relationship between the predicted parameters (i.e., dependent variables) and the independent variables, as well as the percentages of surface contaminants that pose a vulnerability risk. 


\subsection{Subsurface lithostratigraphic and structural characterization}

254 The results of ERT for the surveyed traverses are presented in Figs. 4a-f, while Table 1 presents

255 the results of the VES survey stations points, including the curve types, thicknesses, depths, 256 and descriptions of the delineated subsurface layers. The subsurface layers in Fig. 4a are 257 distinguished by four distinct subsurface layers: motley topsoil, weathered layer, partially 258 weathered/fractured bedrock, and fresh gneissic bedrock, with resistivities ranging from 10$259600 \Omega \mathrm{m}, 600-1000 \Omega \mathrm{m}, 1200 \Omega \mathrm{m}$, and >1200 $\Omega \mathrm{m}$, respectively. The deep-weathered and 260 fractured zones are characterized by varying resistivity signatures due to water saturating fills 261 and aperture sizes. The given ranges of resistivity values also characterize the delineated layers 262 beneath TRs 2-6. Stations $30-55 \mathrm{~m}$ of TR1 are marked by the deep-weathered trough, while 263 thin-to-large apertures are delineated beneath stations $15-18 \mathrm{~m}, 65-70 \mathrm{~m}, 77 \mathrm{~m}$, and 85-115 $\mathrm{m}$. These apertures were enhanced by five penetrative fractures, represented as F1 to F5, as shown in Fig. 4a. The dynamism of water-rock interactions within F4 and F5 resulted in a huge partially weathered bedrock slab between them. The reasonably deep-weathered trough stretching from $140 \mathrm{~m}$ to the end of the model was shown to be characterized by high conductivity subsurface materials. The nature of the subsurface layers beneath TR1 was affirmed by the results of VES 1 and VES 2 at survey stations $67.5 \mathrm{~m}$ and $95 \mathrm{~m}$, which are characterized by KQ and HA curve types, respectively, as presented in Table 1. A typical example of each of the generated curve types is shown in Fig. 5. Beneath the VES surveyed points 1 and 2, the motley topsoil has a thickness of about $1.51 \mathrm{~m}$, and the deepweathered/fractured zones extend to a depth of around $55 \mathrm{~m}$. The number of imaged apertures (i.e., deep-weathered troughs and fractures) with extensive depths is clear evidence of intense deformation, which has contributed significantly to the groundwater conduits and distributions in the study area.

277 The resistivity model of TR2 on the western section with the same parallel profile length as TR1 as shown in Fig. 4b depicts four geologic layers with similar subsurface characteristic features to those identified in TR1. Between surveyed stations $30 \mathrm{~m}$ and $40 \mathrm{~m}$, a fractured zone F6 was delineated, F7 was delineated at the surveyed station $55 \mathrm{~m}$ within the two segmented highly resistive bedrock, e.g., (>1200 $\Omega \mathrm{m})$, and F8 was delineated within the thin-to-large-size weathered and fractured zones between surveyed stations $80 \mathrm{~m}$ and $130 \mathrm{~m}$. The lithostratigraphic section beneath surveyed VES 3 at station $60 \mathrm{~m}$ is defined by an A-resistivity 
curve type as listed in Table 1 . The topsoil is about $1.27 \mathrm{~m}$ thick, and the weathered profile extends to a depth of about $5.67 \mathrm{~m}$. The result of VES 3 coincides with the resistivity model provided in Fig. $4 \mathrm{~b}$ based on the thicknesses of the delineated layers and the depth to fresh bedrock. The observed resistivity signatures beneath the geoelectric surveyed profile of TR3 shown in Fig. 4c mirrored the high resistive zones delineated between geoelectric surveyed stations 20 and $55 \mathrm{~m}$. These zones correlate with partially weathered and resistive bedrock segments outcropping at the near-surface from stations $45-48 \mathrm{~m}$, with resistivity values $>1200$ $\Omega \mathrm{m}$. In addition, low-resistive geoelectric subsurface materials delineated between stations 55$75 \mathrm{~m}$ and $80-100 \mathrm{~m}$, with a resistivity of about $200 \Omega \mathrm{m}$, are identified as water-saturated bedrock troughs that act as part of the groundwater storage features for the study area, e.g., [8]. Apart from the delineated features, two penetrative fractures, i.e., F9 and F10, were imaged between surveyed stations 15 and $25 \mathrm{~m}$, and $50 \mathrm{~m}$ and $60 \mathrm{~m}$, respectively. The VES 4 and VES 5 lithostratigraphic models for geoelectric stations at $45 \mathrm{~m}$ and $58 \mathrm{~m}$ revealed that the motley topsoil and weathered layer beneath TR3 extended to depths of about $3.50 \mathrm{~m}$ and about 10.30 $\mathrm{m}$ at the respective VES surveyed points as shown in Table 1. This affirms that the delineated deep-weathered/fractured zones between 80 and $100 \mathrm{~m}$ are deeper than the imaged depths, as shown in Fig. 4c.

Figure 4. Inverted model resistivity section beneath the geoelectric surveyed traverses.

Table 1: Summary of the generated curve types with the interpreted VES station points.

Figure 5. Typical iterated VES curve types generated for the study area include (a) A type, (b) H type, (c) HA type, and (d) AK type.

Figure 4d, i.e., the resistivity model of TR4, depicts the true nature of the subsurface geologic architecture at the northern section of the studied sites along the NW-SE directions. Just like the other traverses, the delineated low resistivity values beneath this TR4 are characterized by deep-weathered troughs and fractures, i.e., F11-F13, from the starting station point, 40-65 m, 90-105 m, and relatively shallow depths, and could be attributed to the depths and large apertures with water and low resistive crustal materials, e.g., clay. The probable depths of the weathered and fractured zones beneath TR4 are supported by the results of the VES points 6 
and 7 at stations $35 \mathrm{~m}$ and $60 \mathrm{~m}$ as shown in Table 1, respectively. From their results, the topsoil (with a resistivity of about $57.5 \Omega \mathrm{m}$ ) is delineated to be relatively thin, with a thickness of $<1.7$ $\mathrm{m}$ at VES 6, and the saturated to dry sandy weathered materials (i.e., zones with resistivity values between 267.6 and $547 \Omega \mathrm{m}$ ) extend to a depth of about $6.60 \mathrm{~m}$ (but not more than 5.8 $\mathrm{m}$ at VES 7). In addition, a depth of $39 \mathrm{~m}$ was mapped at VES 7, arising from the effect of tectonic deformation that could be attributed to a penetrative fracture that was created by either F12 or F13. In Fig. 4e (i.e., the resistivity model of TR5), the geologic conditions towards the southern section in the same parallel direction as TR4 are clearly depicted. Fig. 4e shows the subsurface crustal architecture similar to those identified in TR4, especially between the surveyed stations of $20 \mathrm{~m}$ and $40 \mathrm{~m}$ and $40 \mathrm{~m}$ and $100 \mathrm{~m}$. TR5 is characterized by varying low resistive zones arising from the weathered materials and fractures (i.e., F14 and F15) that demarcate the rugose fresh bedrock between stations $18 \mathrm{~m}$ and $30 \mathrm{~m}$, and $70 \mathrm{~m}$ and $95 \mathrm{~m}$, respectively. According to the lithostratigraphic results of VES 8 at a surveyed station of $55 \mathrm{~m}$ along TR5, the topsoil has a thickness of about $1.35 \mathrm{~m}$, and the weathered layer has an approximate depth of about $6.52 \mathrm{~m}$, as shown in Table 1 . However, the depth of the weathered column, as presented in Fig. 4e, extended to a depth above $12 \mathrm{~m}$. The subsurface disparities and similarities existing between TRs 4 and 5 are shown in the resistivity model of TR6, i.e., Fig. 4f. The model depicts a thick overburden subsurface geoelectric profile with a high level of water saturation filling the subsurface geologic materials. The edges of the bedrock are only seen in a few sections. The topsoil is thicker and extends to a depth of about $3.8 \mathrm{~m}$ along this particular geoelectric profile. Considering the trends and occurrences of the high resistive features shown in the model generated, six different penetrative fractures, i.e., F16 to F21, were delineated. The model showed that the near-surface geologic features with deep-weathering sections have a high potential for groundwater storage and circulation, especially the central depression with two prominent fractures, e.g., F18 and F19. Based on the surface expression and resistivity model of TR6, the traverse is seen to occur as a depression between TRs 4 and 5; hence, the topographic effect has tremendously contributed to delineated intrinsic crustal features and the hydrodynamics of the deep-weathered and fractured zones. The perfect correlation of the ERT model and VES results significantly proves the accuracy of the methodological (i.e., field and data inversion) approaches adopted for generating the resistivity models for the studied site. 
4.2 Geohydraulic characteristics of tropically weathered and fractured gneissic aquifers and empirical relationships: insights into groundwater yielding potential

The identified weathered and fractured aquifer zones in the study area are characterized by varied aquifer resistivity (i.e., $\rho_{o}$ ), and thickness values ranging from $138-838.10 \Omega \mathrm{m}$, and 3.5-50.10 m, respectively, as presented in Table 2. The estimation of aquifer parameters, e.g., $\mathrm{K}, \mathrm{T}, \varphi$, and $\Psi$, is important for evaluating the groundwater potential of tropically weathered and fractured bedrock aquifers. The estimated $\mathrm{K}$ and $\mathrm{T}$ values for the aquifer zones in the study area ranged from about $0.7246-3.8985 \mathrm{~m} /$ day and about 53079-60.8597 $\mathrm{m}^{2} /$ day, respectively, as listed in Table 2. The value of T above $20 \mathrm{~m}^{2} /$ day was estimated for VES surveyed points 1 , 2, 7, and 8, while the rest of the VES points recorded values far below this estimated value. This variation may have been due to the higher thickness and aperture of the aquifer zones, which provided room for a higher rate of water-rock interaction from water flows, e.g., [3, 8, 16, 17]. As presented in Table 2, the estimated values of $\varphi$ and $\Psi$ for aquifers in the study area ranged from $24.05-31.62 \%$, and $0.103-0.556 \mu \mathrm{m}^{2}$, respectively. The measured range of values for the recorded porosity for the aquifer depicts the dominancy of consolidated weathered materials typical of clay, sand, and lateritic clay, e.g., $[3,7]$. The reduction in porosity at some VES surveyed stations may be due to a decrease in fluid contents, bulk conductivities, and/or a decrease in the hydraulic conductivities, e.g., [7].

Table 2: Estimated values for the geohydraulic and vulnerability parameters of the aquifer units in the study area

The geostatistical results derived from regression analysis as presented in Table 3, provide additional clues on the contribution of each of the independent variables, e.g., T, $\varphi$, and $\Psi$ to the measured $\mathrm{K}$ for aquifer zones in the Araromi area of Akungba-Akoko. The $\mathrm{K}$ model yielded very strong positive correlation coefficient (R) values of about $0.9039,0.9827$, and 1 for $\rho_{o}, \varphi$, and $\Psi$, respectively. However, $\mathrm{T}$ yielded a very weak positive correlation coefficient value of about 0.182 . The observed statistical results affirm that $\rho_{o}, \varphi$, and $\Psi$ are significant in determining $\mathrm{K}$ for aquifer potential, with percentages of $81.7 \%, 96.6 \%$, and $100 \%$, respectively, based on the coefficient of determination $\left(R^{2}\right)$ results. However, the percentage contribution of $\mathrm{T}$ to the $\mathrm{K}$ of aquifers in the study area is about $3.31 \%$, as listed in Table 3 . The 
$\rho_{o}$ and $\mathrm{T}$ decline with the aquifer $\mathrm{K}$ at a rate of 0.0046 and 0.0112 , while $\varphi$, and $\Psi$ increase at a rate of 0.4342 and 7.0089 , respectively. The low percentage contribution of $\mathrm{T}$, which may reduce aquifer transmissivity, could be attributed to the high resistivity values of some aquifers and the occlusion of the deep-weathered and fractured zones by soils produced secondary weathering. The observed $R^{2}$ values suggest that the model fitted reasonably well with the used variables for the determination of $\mathrm{K}[3,42,43]$, except for $\mathrm{T}$. In addition, the high percentage $R^{2}$ contributions of both porosity and permeability to the $\mathrm{K}$ model suggest a significant contribution of both parameters to water-rock interactions, and the ease of fluids transmissibility in water-bearing aquifer units, e.g., $[3,7,8]$. The estimated standard errors offered the variability determination of the coefficients and a significant non-zero slope. The above-evaluated parameters have low coefficient standard errors; hence, suggesting very low statistical variation. The $T$-stat values with corresponding $p$-values were used to determine the accuracy and robustness of the analysis. The above dependent variables (i.e., $\rho_{o}, \varphi$, and $\Psi$ ) yielded $p \leq 0.05$, except for $\mathrm{T}$; hence, this significantly validates the accuracy of the geostatistical model. The lower and upper 95\% confidence limits ranging from about -0.0067 to $-0.0024,-0.0714$ to $0.0491,0.3525-0.5158$, and $7.0021-7.0157$ for $\rho_{o}, \mathrm{~T}, \varphi$, and $\Psi$, respectively in Table 3, account for the unknown $\mathrm{K}$ values [3, 42-44]. The empirical relationships between $\mathrm{K}$ and the parameters $\rho_{o}, \mathrm{~T}, \varphi$, and $\Psi$, were derived from their listed values in Table 3, and are given in Equations 7-10, respectively.

$$
\begin{aligned}
& K=-0.0046 \rho_{o}+3.862 \\
& K=-0.0112 T+1.9918 \\
& K=0.4342 \varphi-10.060 \\
& K=7.0089 \Psi+0.0014
\end{aligned}
$$

According to the reports of Krasny [45] and Akingboye et al. [3], classifications of the magnitude of aquifer transmissivity for the evaluation of groundwater-yielding capacity presented in Table 4, classify the aquifer potential types in the study area into the low and moderate groundwater-yielding capacity aquifer zones. These aquifer types are efficient for water withdrawal at smaller quantities, (i.e., local groundwater supply), the typical rate for private/personal consumption, and also for smaller communities based on water transmissible rates. However, delineated aquifer zones with deeper depths fractures exceeding $39 \mathrm{~m}$ and higher porosity and permeability values above $30 \%$ and $0.4 \mu \mathrm{m}^{2}$ respectively (see Table 2), 
have higher groundwater-yielding capacity. The results further affirm that aquifer transmissibility depends on the physical characteristics of the subsurface geologic units.

Table 3: Regression coefficients from the model of hydraulic conductivity against other estimated aquifer parameters for the study area

Table 4: Classifications of the magnitudes of aquifer transmissivity for the study area (modified after Akingboye et al. [3] and Krasny [45])

\subsection{Evaluation of the vulnerability of aquifer zones in the study area}

The evaluation of aquifer vulnerability in the study area depends on the estimation of the longitudinal conductance $\mathrm{S}$ and hydraulic resistance $\mathrm{K}_{R}$, to classify the aquifer protective capacity (APC) and aquifer vulnerability index (AVI). The $\mathrm{K}_{R}$ is an essential geological formation factor to determine the resistance of an aquifer to vertical fluids flow through the protective subsurface strata because it depends on $\mathrm{K}$ but varied inversely proportional to it. The relationship between the AVI and the logarithm of the hydraulic resistance, i.e., $\log \mathrm{K}_{R}$, for the VES surveyed station points are as shown in Table 5. In addition to the parameters, the thicknesses of aquifers in the study area were taken into consideration while evaluating the aquifer vulnerability. The $\mathrm{S}$ of the tropically weathered and fractured gneissic aquifers units in the study area ranged from about $0.0226-0.1926$ mhos, as presented in Table 2 . The $\mathrm{K}_{R}$, on the other hand, varied between 1.02 and 58.37, while the $\log \mathrm{K}_{R}$ varied from about 0.01-1.77 years. The regression analysis of the $\mathrm{K}$ model reveals that the $\mathrm{S}$ of aquifer units in the study area has weak positive correlation values of about 0.341 , with a significant percentage contribution of about $11.63 \%$ with and an adjusted coefficient of -0.031 based on the results of the $R^{2}$ and adjusted $R^{2}$, respectively, as presented in Table 3 . The $\mathrm{K}_{R}$ yielded a moderate positive correlation of about 0.5769 with $\mathrm{K}$. This parameter contributed about $33.29 \%$ to the estimated $\mathrm{K}$ model. The weak positive correlation between $\mathrm{K}$ and $\mathrm{S}$ implies that both parameters are independent of one another just as explained above, the lower and upper 95\% confidence limits derived for the $\mathrm{S}$ and $\mathrm{K}_{R}$ account for the unknown $\mathrm{K}$ values that are not presented in Table 3. The $\mathrm{K}$ is statistical related to $\mathrm{S}$ and $\mathrm{K}_{R}$ through Equations 11 and 12, respectively, which were derived from model results in Table 3 . It is worth noting that the $\mathrm{K}$ 
values for the tropically weathered and fractured gneissic aquifer zones in the study area can be determined using any of the empirical relations provided in Equations 7-12 from the regression analysis.

$$
\begin{aligned}
& K=-6.2143 S+2.19 \\
& K=-0.0305 \mathrm{~K}_{R}+2.3242
\end{aligned}
$$

Following the reports of Oladapo et al. [39] and Akingboye et al. [3], the identified aquifer zones at the VES surveyed station points 3-6, and 8 , and the VES points 1, 2, and 7, are characterized by poor to weak and moderate aquifer protection capacity (i.e., APC), with the values of S ranging from about $<0.1-0.19$ mho and $0.2-0.69$ mho, respectively, as presented in Table 5. These characterized ranges of values coincide with the range of values for $\log \mathrm{K}_{R}$, as suggested by Van Stempvoort et al. [40], which measures AVI by hydraulic resistance. Hence, the aquifer zones were classified by the AVI into poor/weak and moderate APC, with extremely high vulnerability and high vulnerability as presented in Table 5. These results suggest that the Araromi area of Akungba-Akoko has poor/weak to moderate APC with extremely high AVI and high AVI, respectively, due to the generally thin overburden soil material cover and low hydraulic resistance, e.g., [3, 46]. Protective layers with suitable thickness and low hydraulic conductivity provide effective groundwater protection, resulting in a long residence time for infiltrating water. Based on the APC and AVI results, intended wells and boreholes in the study area will require adequate protection against infiltrating contaminants for the provision of sustainable potable groundwater supplies for the inhabitants of the area and surrounding locations. The results derived for the present study area conform with the reports on groundwater potential and vulnerability of the Etioro-Akoko community in the works of Akingboye et al. [3] and Akingboye \& Osazuwa [21]. This study, therefore, affirms that both neighboring communities are characterized by the same near-surface hydrodynamics and aquifer vulnerability conditions.

Table 5: Comparison of standard values for the longitudinal conductance, protective capacity rating, and classification of the aquifer vulnerability index, based on the hydraulic resistance calculated for the study area. 


\section{Conclusions}

468 The geohydraulic characteristics and vulnerability of tropically weathered and fractured gneissic aquifers in the Araromi area of Akungba-Akoko, southwestern Nigeria, have been assessed using a combination of ERT, VES, and geostatistical (i.e., regression analysis) methods. The results of the resistivity models revealed four distinct layers. The motley topsoil is generally thin (i.e., $<1.7 \mathrm{~m}$ ) in most sections, but thickness values ranging from about $2.5-$

$4733.5 \mathrm{~m}$ were recorded at VES 4 and VES 5 along TR3. Just like the areas within the Akungba474 Akoko and Etioro-Akoko, the thickness of the overburden is also generally $<4 \mathrm{~m}$, except for deep-weathered and fractured bedrock sections that extend to depths above $39 \mathrm{~m}$, and such characteristic features are localized in the study area.

The regression analysis revealed that the $\rho_{o}, \mathrm{~T}, \varphi$, and $\Psi$, contributed significantly, about $81.7 \%, 3.31 \%$. $96.6 \%$, and $100 \%$, respectively, to the determination of $\mathrm{K}$ for aquifers in the study area. Based on the delineated lithostratigraphic units, subsurface geologic structures, and their varying depths, as well as the geohydraulic characteristics, the aquifer units in the study area are classified as having low to moderate groundwater-yielding potential. However, the enhanced fractured aquifer zones to depths above $55 \mathrm{~m}$ can produce adequate groundwater yield in some places in the area. The reported S values (i.e., 0.0226-0.1926 mho) for APC ratings in the Araromi area of Akungba-Akoko were too low, and thus, the APC ratings are rated poor/weak to moderately high with an extremely high to high AVI. It is, therefore, important that intended wells and/or boreholes in the study area and any environments with similar geohydraulic characteristics and vulnerability ratings should ensure proper construction designs for adequate protection against both surface and subsurface infiltrating contaminants. This study has provided significant insights into the assessment of sustainable potable groundwater development in crystalline basement geologic environments using integrated geophysical resistivity and regression analytical approaches.

\section{Acknowledgments}

The Department of Earth Sciences, Adekunle Ajasin University, is appreciated for providing the field equipment used for this study. Ayanfe Moses Asulewon (formerly of the Department of Earth Sciences, Adekunle Ajasin University) is acknowledged for his assistance during the field data acquisition. I also thank the Geophysics Unit, School of Physics, Universiti Sains 
497 Malaysia, for providing adequate facilities and a congenial environment to conduct this 498 research.

\section{Data Availability}

500 All data generated or analyzed during this study are included in this published article. Other supporting analyzed data can be made available by the corresponding author upon reasonable 502 request.

\section{Funding}

This research did not receive any specific grants from funding agencies in the public, commercial, or not-for-profit sectors.

\section{Declaration of competing interest}

507 The authors declare that they have no known competing financial interests or personal relationships that could have appeared to influence the work reported in this paper.

\section{References}

[1] M. E. Ofodile, "Groundwater study and development in Nigeria. Mecon Geology, Jos", (2014).

[2] W. J. Cosgrove \& D. P. Loucks, "Water management: current and future challenges and research directions", Water Resources Research 51 (2015) 4823.

[3] A. S. Akingboye, A. A. Bery, A. C. Ogunyele, A. O. Adeola, O. O. Omojola \& A. S. Adesida, "Groundwater-yielding capacity, water-rock interaction, and vulnerability assessment of typical gneissic hydrogeologic units using geoelectrohydraulic method", (Forthcoming).

[4] S. Sajeena, V. M. Abdul Hakkim \& E. K. Kurien, "Identification of groundwater prospective zones using geoelectrical and electromagnetic surveys", International Journal of Engineering Inventions 3 (2014) 17.

] D. N. Obiora, A. E. Ajala \& J. C. Ibuot, "Evaluation of aquifer protective capacity of overburden unit and soil corrosivity in Makurdi, Benue State, Nigeria, using electrical resistivity method", Journal of Earth Systems Science 124 (2015) 125. 
[6] I. Stober \& K. Bucher, "Hydraulic conductivity of fractured upper crust: insights from hydraulic tests in boreholes and fluid-rock interaction in crystalline basement rocks", Geofluids 15 (2015a) 161. https://doi.org/10.1111/gfl.12104

[7] N. J. George, A. E. Akpan \& F. S. Akpan, "Assessment of spatial distribution of porosity and aquifer geohydraulic parameters in parts of the Tertiary - Quaternary hydrogeoresource of south-eastern Nigeria", NRIAG Journal of Astronomy and Geophysics 6 (2017) 422. https://doi.org/10.1016/j.nrjag.2017.09.001

[8] A. S. Akingboye, A. A. Bery, J. S. Kayode, A. M. Asulewon, R. Bello \& O. C. Agbasi, "Near-surface crustal architecture and geohydrodynamics of the gneissic terrain of Araromi, Akungba-Akoko, SW Nigeria, derived from multi-geophysical methods", Natural Resources Research (in press).

[9] A. M. MacDonald, H. C. Bonsor, B. E. O. Dochartaigh \& R. G. Taylor, "Quantitative map of groundwater resource in Africa" Environmental Research Letters 7 (2012) 024009 .

[10] M. L. Hossain, S. R. Das \& M. K. Hossain, "Impact of landfill leachate on surface and groundwater quality", Journal of Environmental Science and Technology 7 (2014) 337.

[11] G. O. Mosuro, K. O. Omosanya, O. O. Bayewu, M. O. Oloruntola, T. A. Laniyan, O. Atobi, M. Okubena, E. Popoola \& F. Adekoya, "Assessment of groundwater vulnerability to leachate infiltration using electrical resistivity method", Applied Water Science 7 (2016) 2195. https://doi.org/10.1007/s13201-016-0393-4

[12] W. O. Raji \& K. A. Abdulkadri, "Evaluation of groundwater potential of bedrock aquifers in Geological Sheet 223 Ilorin, Nigeria, using geo-electric sounding", Applied Water Science 10 (2020) 220. https://doi.org/10.1007/s13201-020-01303-2

[13] M. Hasan, Y. Shang, G. Akhter \& M. Khan, "Geophysical investigation of fresh-saline water interface: a case study from South Punjab, Pakistan”, Groundwater 55 (2017) 841.

[14] A. S. Akingboye \& A. A. Bery, "Evaluation of lithostratigraphic units and groundwater potential using the resolution capacities of two different electrical tomographic electrodes at dual-spacing", Contributions to Geophysics and Geodesy, 51 (2021a).

[15] A. S. Akingboye \& A. A. Bery, "Borehole-constrained ERT for mapping the soil-rock interface in a granitic environment: implications on groundwater, engineering structures, and plant roots", (Forthcoming) 33p. 
[16] M. Hasan, Y. Shang, W. Jin \& G. Akhter, "Estimation of hydraulic parameters in a hard rock aquifer using integrated surface geoelectrical method and pumping test data in southeast Guangdong, China”, Geosciences Journal (2020a). https://doi.org/10.1007/s12303-020-0018-7

[17] M. Hasan, Y. Shang, G. Akhter \& W. Jin, "Delineation of contaminated aquifers using integrated geophysical methods in Northeast Punjab, Pakistan. Environmental Monitoring and Assessment 192 (2020b) 12. https://doi.org/10.1007/s10661-019-7941-y

[18] A. M. Ekanem, "Georesistivity modelling and appraisal of soil water retention capacity in Akwa Ibom State University main campus and its environs, southern Nigeria", Modeling Earth Systems and Environment (2020). https://doi.org/10.1007/s40808-020$\underline{00850-6}$

[19] M. Z. Mohammed, T. H. T. Ogunribido \& A. T. Funmilayo, "Electrical resistivity sounding for subsurface delineation and evaluation of groundwater potential of Araromi Akungba-Akoko Ondo State southwestern Nigeria", Journal of Environmental Earth Sciences 2 (2012) 29.

[20] M. B. Aminu, "Electrical resistivity imaging of a thin clayey aquitard developed on basement rocks in parts of Adekunle Ajasin University Campus, Akungba-Akoko, southwestern Nigeria”, Environmental Research, Engineering and Management 71 (2015) 47. http://doi.org/10.5755/j01.erem.71.1.9016

[21] A. S. Akingboye \& I. B. Osazuwa, "Subsurface geological, hydrogeophysical, and engineering characterisation of Etioro-Akoko, southwestern Nigeria, using electrical resistivity tomography”, NRIAG Journal of Astronomy and Geophysics, 9 (2021) 43. https://doi.org/10.1080/20909977.2020.1868659

[22] M. A. Rahaman, "Review of the Basement Geology of southwestern Nigeria. In: C. A. Kogbe, (eds.) Geology of Nigeria. Elizabeth Publisher. Co., Lagos”, (1976) 41.

[23] M. A. Rahaman, "Recent advances in the study of the Basement Complex of Nigeria. In: P. O. Oluyide, W. C. Mbonu, A. E. O. Ogezi, I. G. Egbuniwe, A. C. Ajibade \& A. C. Umeji, (eds.) Precambrian Geology of Nigeria. Geological Survey of Nigeria, Kaduna", (1988) 11. 
[24] A. Kröner, B. N. Ekwueme \& R. T. Pidgeon, "The Oldest Rocks in West Africa: SHRIMP Zircon Age for Early Archean Migmatitic Orthogneiss at Kaduna, Northern Nigeria”, The Journal of Geology 109 (2001) 399.

[25] B. J. Fagbohun, A. A. Omitogun, O. A. Bamisaiye \& F. J. Ayoola, "Remote detection and interpretation of structural style of the Zuru Schist Belt, northwest Nigeria", Geocarto International (2020) 1. https://doi.org/10.1080/10106049.2020.1753822

[26] E. Ferré, G. Gleizes \& R. Caby, "Obliquely convergent tectonics and granite emplacement in the Trans-Saharan belt of Eastern Nigeria: a synthesis", Precambrian Research 144 (2002) 199.

[27] A. C. Ogunyele, S. O. Obaje, A. S. Akingboye, A. O. Adeola, A. O. Babalola \& A. T. Olufunmilayo, "Petrography and geochemistry of Neoproterozoic charnockite-granite association and metasedimentary rocks around Okpella, southwestern Nigeria", Arabian Journal of Geosciences 13 (2020) 780. https://doi.org/10.1007/s12517-020-05785-x

[28] M. Woakes, M. A. Rahaman \& A. C. Ajibade. "Some metallogenetic features of the Nigerian Basement", Journal of African Earth Sciences 6 (1987) 655. https://doi.org/10.1016/0899-5362(87)90004-2

[29] A. S. Akingboye, A. C. Ogunyele, A. T. Jimoh, O. B. Adaramoye, A. O. Adeola \& T. Ajayi, "Radioactivity, radiogenic heat production and environmental radiation risk of the Basement Complex rocks of Akungba-Akoko, southwestern Nigeria: insights from in situ gamma-ray spectrometry", Environmental Earth Sciences 80 (2021b) 6. https://doi.org/10.1007/s12665-021-09516-7

[30] P. I. Olasehinde \& W. O. Raji, "Geophysical studies on fractures of basement rocks at the University of Ilorin, southwestern Nigeria: application to groundwater exploration", Water Resources Research 17 (2007) 3.

[31] M. H. Loke, "Rapid 2D resistivity and IP inversion using the least-square method. Manual for RES2DINV, version 3.54”, (2004) 53.

[32] A. S. Akingboye \& A. C. Ogunyele, "Insight into seismic refraction and electrical resistivity tomography techniques in subsurface investigations", Rudarsko Geolosko Naftni Zbornik 34 (2019) 93. https://doi.org/10.17794/rgn.2019.1.9

[33] C. DeGroot-Hedlin \& S. C. Constable, “Occam's inversion to generate smooth twodimensional models from magnetotelluric data”, Geophysics 55 (1990) 1613. 
[34] T. Dahlin \& M. H. Loke, "Underwater ERT surveying in water with resistivity layering with example of application to site investigation for a rock tunnel in central Stockholm", Near Surface Geophysics 16 (2018) 230. https://doi.org/10.3997/1873-0604.2018007

[35] A. S. Akingboye \& A. A. Bery, "Performance evaluation of copper and stainless-steel electrodes in electrical tomographic imaging”, Journal of Physical Science 32 (2021b).

[36] P. C. Heigold, R. H. Gilkeson, K. Cartwright \& P. C. Reed, “Aquifer transmissivity from surficial electrical methods", Ground Water 17 (1979) 338.

[37] S. Niwas \& D. C. Singhal, "Estimation of aquifer transmissivity from Dar-Zarrouk parameters in porous media”, Journal of Hydrology 50 (1981) 393.

[38] A. A. R. Zohdy, G. P. Eaton \& D. R. Mabey, "Application of surface geophysics to groundwater investigations. United State Geophysical Survey, Washington”, (1974).

[39] M. I. Oladapo, M. Z. Mohammed, O. O. Adeoye \& O. O. Adesola, "Geoelectric investigation of the Ondo State Housing Corporation Estate Ijapo, Akure, southwestern Nigeria”, Journal of Mining Geology 40 (2004) 41.

[40] D. Van Stempvoort, L. Ewert \& L. Wassenaar, "Aquifer vulnerability index: a GIScompatible method for groundwater vulnerability mapping", Canadian Water Resources Journal 18 (1992) 25.

[41] Fetters, C.W. 1994. Applied hydrogeology, (3rd edn). Prentice Hall Inc., New Jersey, p 600.

[42] R. J. Freund, W. J. Wilson \& D. L. Mohr, “Statistical Methods (3 $3^{\text {rd }}$ ed.)”, Elsevier Inc., (2010). https://doi.org/10.1016/C2009-0-20216-9

[43] G. Smith, "Essential Statistics, Regression, and Econometrics”, Elsevier Inc., (2011). https://doi.org/10.1016/C2009-0-61163-6

[44] A. S. Akingboye, O. Ademila, C. C. Okpoli, A. V. Oyeshomo, et al., "Radiogeochemistry, uranium migration and radiogenic heat of the granite gneisses in parts of the southwestern Basement Complex of Nigeria", Journal of African Earth Sciences (in press).

[45] J. Krasny, "Classification of transmissivity magnitude and variation", Groundwater 31 (1993) 230. 
644 [46] O. J. Akintorinwa, M. O. Atitebi \& A. A. Akinlalu, "Hydrogeophysical and aquifer 645

Idanre southwestern Nigeria”,

Heliyon

6

(2020). https://doi.org/10.1016/j.heliyon.2020.e04549 
649 Table 1: Summary of the generated curve types with the interpreted VES station points.

\begin{tabular}{|c|c|c|c|c|c|c|c|}
\hline Traverse & $\begin{array}{l}\text { VES } \\
\text { point }\end{array}$ & $\begin{array}{l}\text { Station } \\
\text { (m) }\end{array}$ & $\begin{array}{l}\text { Curve } \\
\text { type }\end{array}$ & $\begin{array}{l}\text { Resistivity } \\
\text { values } \\
(\Omega \mathrm{m}) \\
\end{array}$ & $\begin{array}{l}\text { Thickness, } \\
\text { h (m) }\end{array}$ & $\begin{array}{l}\text { Depth, } \\
\text { H (m) }\end{array}$ & Geoelectric interpretation \\
\hline \multirow[t]{4}{*}{ TR1 } & \multirow[t]{4}{*}{ VES1 } & \multirow[t]{4}{*}{67.5} & \multirow[t]{4}{*}{ KQ } & 19.4 & 1.16 & 1.16 & Motley topsoil (clay rich) \\
\hline & & & & 7847 & 7.44 & 8.60 & Fresh gneissic bedrock slab \\
\hline & & & & 415 & 43.60 & \multirow[t]{2}{*}{52.20} & \multirow{2}{*}{$\begin{array}{l}\text { Deep weathered } \\
\text { trough/fractured bedrock } \\
\text { (water-saturated column) }\end{array}$} \\
\hline & & & & 143 & ---- & & \\
\hline \multirow[t]{4}{*}{ TR1 } & \multirow[t]{4}{*}{ VES2 } & \multirow[t]{4}{*}{95} & \multirow[t]{4}{*}{ HA } & 110 & 1.51 & 1.51 & Motley topsoil \\
\hline & & & & 29.2 & 3.13 & 4.64 & $\begin{array}{l}\text { Water-saturated weathered } \\
\text { trough }\end{array}$ \\
\hline & & & & 699 & 50.10 & 54.80 & Fractured bedrock slab \\
\hline & & & & 912 & ---- & & Partially weathered trough. \\
\hline \multirow[t]{3}{*}{ TR2 } & \multirow[t]{3}{*}{ VES3 } & \multirow[t]{3}{*}{60} & \multirow[t]{3}{*}{ A } & 106 & 1.27 & 1.27 & Motley topsoil \\
\hline & & & & 415 & 4.40 & 5.67 & Sandy weathered trough \\
\hline & & & & 2736 & ---- & & Fresh gneissic bedrock \\
\hline \multirow[t]{3}{*}{ TR3 } & \multirow[t]{3}{*}{ VES4 } & \multirow[t]{3}{*}{45} & \multirow[t]{3}{*}{$\mathrm{A}$} & 158 & 3.50 & 3.50 & Motley topsoil \\
\hline & & & & 1218 & 12.7 & 16.20 & \multirow{2}{*}{$\begin{array}{l}\text { Gradually increasing resistive } \\
\text { fresh bedrock slab }\end{array}$} \\
\hline & & & & 5207 & ---- & & \\
\hline \multirow[t]{3}{*}{ TR3 } & \multirow[t]{3}{*}{ VES5 } & \multirow[t]{3}{*}{58} & \multirow[t]{3}{*}{ A } & 137 & 2.59 & 2.59 & Motley topsoil \\
\hline & & & & 521 & 7.71 & 10.30 & Sandy weathered trough \\
\hline & & & & 1288 & ---- & & Fresh bedrock slab \\
\hline \multirow[t]{3}{*}{ TR4 } & \multirow[t]{3}{*}{ VES6 } & \multirow[t]{3}{*}{35} & \multirow[t]{3}{*}{ A } & 57.5 & 1.68 & 1.68 & Motley topsoil \\
\hline & & & & 547 & 4.92 & 6.60 & Sandy weathered trough \\
\hline & & & & 7451 & ---- & & Fresh bedrock slab \\
\hline \multirow[t]{4}{*}{ TR4 } & \multirow[t]{4}{*}{ VES7 } & \multirow[t]{4}{*}{60} & \multirow[t]{4}{*}{ AK } & 53.42 & 1.30 & 1.30 & Motley topsoil \\
\hline & & & & 267.6 & 4.50 & 5.80 & $\begin{array}{l}\text { Saturated sandy weathered } \\
\text { trough }\end{array}$ \\
\hline & & & & 2476 & 33.15 & 38.95 & Fresh bedrock slab \\
\hline & & & & 838.1 & ---- & & Fractured bedrock column \\
\hline TR5 & VES8 & 55 & $\mathrm{H}$ & 567 & 1.35 & 1.35 & Motley topsoil \\
\hline & & & & 138 & 5.17 & 6.52 & Sandy clay weathered trough \\
\hline & & & & 3872 & ---- & & Fresh bedrock slab \\
\hline
\end{tabular}

650 
652 Table 2: Estimated values for the geohydraulic and vulnerability parameters of the aquifer units 653 in the study area

\begin{tabular}{cccccccccc}
\hline $\begin{array}{c}\text { VES } \\
\text { point }\end{array}$ & $\begin{array}{c}\boldsymbol{\rho}_{\boldsymbol{o}} \\
(\mathbf{\Omega m})\end{array}$ & $\begin{array}{c}\mathbf{h} \\
(\mathbf{m})\end{array}$ & $\begin{array}{c}\mathbf{K} \\
(\mathbf{m} / \mathbf{d a y})\end{array}$ & $\begin{array}{c}\mathbf{T} \\
\left(\mathbf{m}^{2} / \mathbf{d a y}\right)\end{array}$ & $\begin{array}{c}\boldsymbol{\varphi} \\
\mathbf{( \% )}\end{array}$ & $\begin{array}{c}\Psi \\
\left(\boldsymbol{\mu m}^{2}\right)\end{array}$ & $\begin{array}{c}\boldsymbol{S} \\
(\mathbf{m h o})\end{array}$ & $\mathrm{K}_{R}$ & $\begin{array}{c}\mathbf{L o g} \mathrm{K}_{R} \\
(\mathbf{y e a r})\end{array}$ \\
\hline 1 & 415 & 43.60 & 1.3959 & 60.8597 & 27.00 & 0.1990 & 0.1658 & 31.24 & 1.49 \\
2 & 699 & 50.10 & 0.8583 & 42.9993 & 24.81 & 0.1220 & 0.1926 & 58.37 & 1.77 \\
3 & 415 & 4.40 & 1.3959 & 6.1418 & 27.00 & 0.1990 & 0.0226 & 3.15 & 0.50 \\
4 & 158 & 3.50 & 3.4361 & 12.0263 & 31.05 & 0.4900 & 0.0326 & 1.02 & 0.01 \\
5 & 521 & 7.71 & 1.1290 & 8.7045 & 26.05 & 0.1610 & 0.0337 & 6.83 & 0.83 \\
6 & 547 & 4.92 & 1.0788 & 5.3079 & 25.84 & 0.1540 & 0.0382 & 4.56 & 0.66 \\
7 & 838.1 & 34.00 & 0.7246 & 24.6364 & 24.05 & 0.1030 & 0.0545 & 46.92 & 1.67 \\
8 & 138 & 5.17 & 3.8985 & 20.1551 & 31.62 & 0.5560 & 0.0398 & 1.33 & 0.12 \\
\hline
\end{tabular}

654

655 Table 3: Regression coefficients from the model of hydraulic conductivity against other 656 estimated aquifer parameters for the study area

\begin{tabular}{|c|c|c|c|c|c|c|c|}
\hline $\begin{array}{l}\text { Regression } \\
\text { Statistics for } \\
\text { K (m/day) } \\
\text { Model }\end{array}$ & $\rho_{o}(\Omega \mathrm{m})$ & $\mathbf{T}\left(\mathbf{m}^{2} /\right.$ day $)$ & $\varphi(\%)$ & $\Psi\left(\mu \mathbf{m}^{2}\right)$ & $S$ (mho) & $\mathrm{K}_{R}$ & \\
\hline Multiple R & 0.9039 & 0.1820 & 0.9827 & 1.000 & 0.3410 & 0.5769 & \\
\hline R Square $\left(R^{2}\right)$ & 0.8170 & 0.0331 & 0.9658 & 1.000 & 0.1163 & 0.3329 & \\
\hline Adjusted $R^{2}$ & 0.7865 & -0.1280 & 0.9601 & 1.000 & -0.0310 & 0.2217 & \\
\hline Standard error & 0.5629 & 1.2941 & 0.2434 & 0.001 & 1.2372 & 1.0749 & \\
\hline Observations & 8 & & & & & & \\
\hline \multirow[t]{2}{*}{ K Model } & Intercept & Coefficients & $\begin{array}{l}\text { Standard } \\
\text { error }\end{array}$ & T Stat & p-value & \multicolumn{2}{|c|}{$\begin{array}{l}\text { 95\% Confidence } \\
\text { Limits }\end{array}$} \\
\hline & & & & & & Lower & Upper \\
\hline$\rho_{o}(\Omega \mathrm{m})$ & 3.8620 & -0.0046 & 0.0009 & -5.1763 & 0.0021 & -0.0067 & -0.0024 \\
\hline $\mathrm{T}\left(\mathrm{m}^{2} /\right.$ day $)$ & 1.9918 & -0.0112 & 0.0246 & -0.4533 & 0.6663 & -0.0714 & 0.0491 \\
\hline$\varphi(\%)$ & -10.060 & 0.4342 & 0.0334 & 13.0151 & 0.0000 & 0.3525 & 0.5158 \\
\hline$\Psi\left(\mu \mathrm{m}^{2}\right)$ & 0.0014 & 7.0089 & 0.0028 & 2523.28 & 0.0000 & 7.0021 & 7.0157 \\
\hline$S$ (mho) & 2.1900 & -6.2143 & 6.9944 & -0.8885 & 0.4085 & -23.3290 & 10.9004 \\
\hline $\mathrm{K}_{R}$ & 2.3242 & -0.0305 & 0.0176 & -1.7302 & 0.1343 & -0.0736 & 0.0126 \\
\hline
\end{tabular}

$657 K$ implies geohydraulic conductivity, which is the dependent variable. 
658 Table 4: Classifications of the magnitudes of aquifer transmissivity for the study area (modified 659 after Akingboye et al. [3] and Krasny [45])

\begin{tabular}{llll}
\hline $\mathbf{T ~}\left(\mathbf{m}^{\mathbf{2}} / \mathbf{d a y}\right)$ & $\begin{array}{l}\text { Aquifer } \\
\text { potential }\end{array}$ & Groundwater-yielding potential & $\begin{array}{l}\text { Geoelectric VES } \\
\text { station points of the } \\
\text { study area }\end{array}$ \\
\hline$>1000$ & Very high & Very high withdrawal of great regional importance & \\
$100-1000$ & High & Withdrawal of lesser regional importance & $1,2,4,7, \& 8$ \\
$10-100$ & Moderate & $\begin{array}{l}\text { Withdrawal of local water supply (e.g., small } \\
\text { community) }\end{array}$ & $3,5, \& 6$ \\
$1-10$ & Low & $\begin{array}{l}\text { Smaller withdrawal for local water supply (private } \\
\text { consumption) }\end{array}$ & \\
$0.1-1$ & Very low & $\begin{array}{l}\text { Withdrawal of local water supply with limited } \\
\text { consumption }\end{array}$ & \\
\hline 0.1 & Negligible & Impermeable sources for local water supply are difficult & \\
\hline
\end{tabular}

660

661 Table 5: Comparison of standard values for the longitudinal conductance, protective capacity 662 rating, and classification of the aquifer vulnerability index, based on the hydraulic resistance 663 calculated for the study area.

\begin{tabular}{|c|c|c|c|c|}
\hline $\begin{array}{l}\text { Longitudinal } \\
\text { conductance, } S \\
(\mathbf{m h o})\end{array}$ & APC rating & $\begin{array}{l}\log \mathrm{K}_{R} \\
\text { (year) }\end{array}$ & AVI & $\begin{array}{l}\text { AVI of VES points in } \\
\text { relation to APC based on } \\
\text { Log } \mathrm{K}_{R}\end{array}$ \\
\hline \multicolumn{2}{|c|}{$\begin{array}{l}\text { modified after Akingboye et al. [3] \& } \\
\text { Oladapo et al. [39] }\end{array}$} & \multicolumn{2}{|c|}{ Van Stempvoort et al. [40] } & Present study area \\
\hline$>10$ & Excellent & $>4$ & Extremely low vulnerability & \\
\hline $5-10$ & Very good & $3-4$ & Low vulnerability & \\
\hline $0.7-4.9$ & Good & $2-3$ & Moderate vulnerability & \\
\hline $0.2-0.69$ & Moderate & $1-2$ & High vulnerability & $1,2, \& 7$ \\
\hline$<0.1-0.19$ & Poor - weak & $<1$ & $\begin{array}{l}\text { Extremely high } \\
\text { vulnerability }\end{array}$ & $3-6, \& 8$ \\
\hline
\end{tabular}



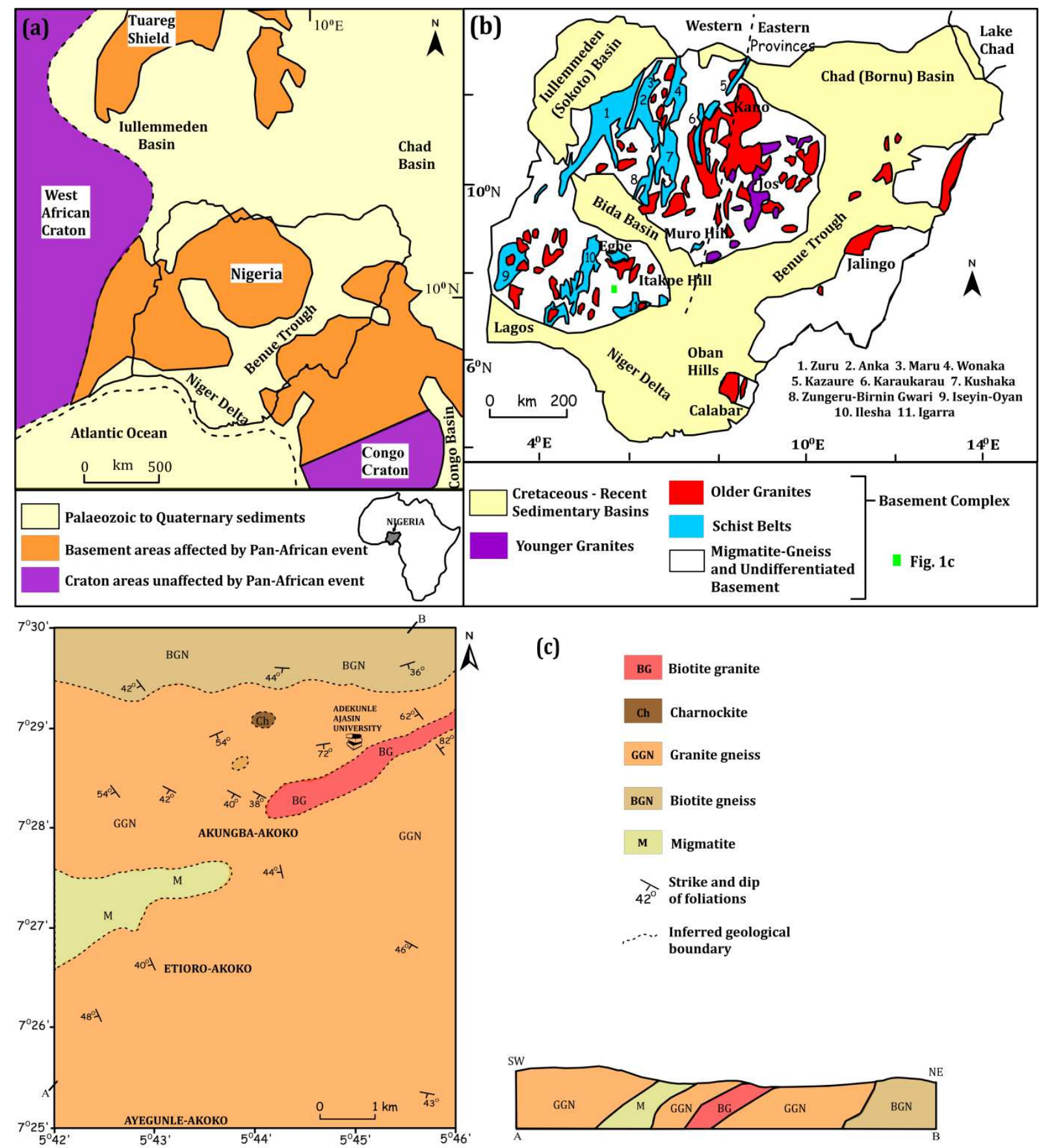

(c)

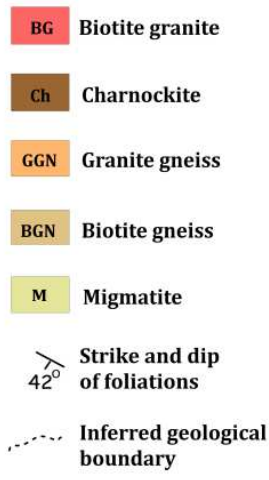

Figure 1. (a) Nigeria's regional geological map within the Pan-African mobile belt between the

668 West African and Congo Cratons. (b) A detailed regional geological map of Nigeria showing 669 the study area in the Nigerian Southwestern Basement Complex (modified after [28]). (c)

670 Geological map of Akungba-Akoko and its surroundings in Ondo State, southwestern Nigeria 671 (modified from [21]). 


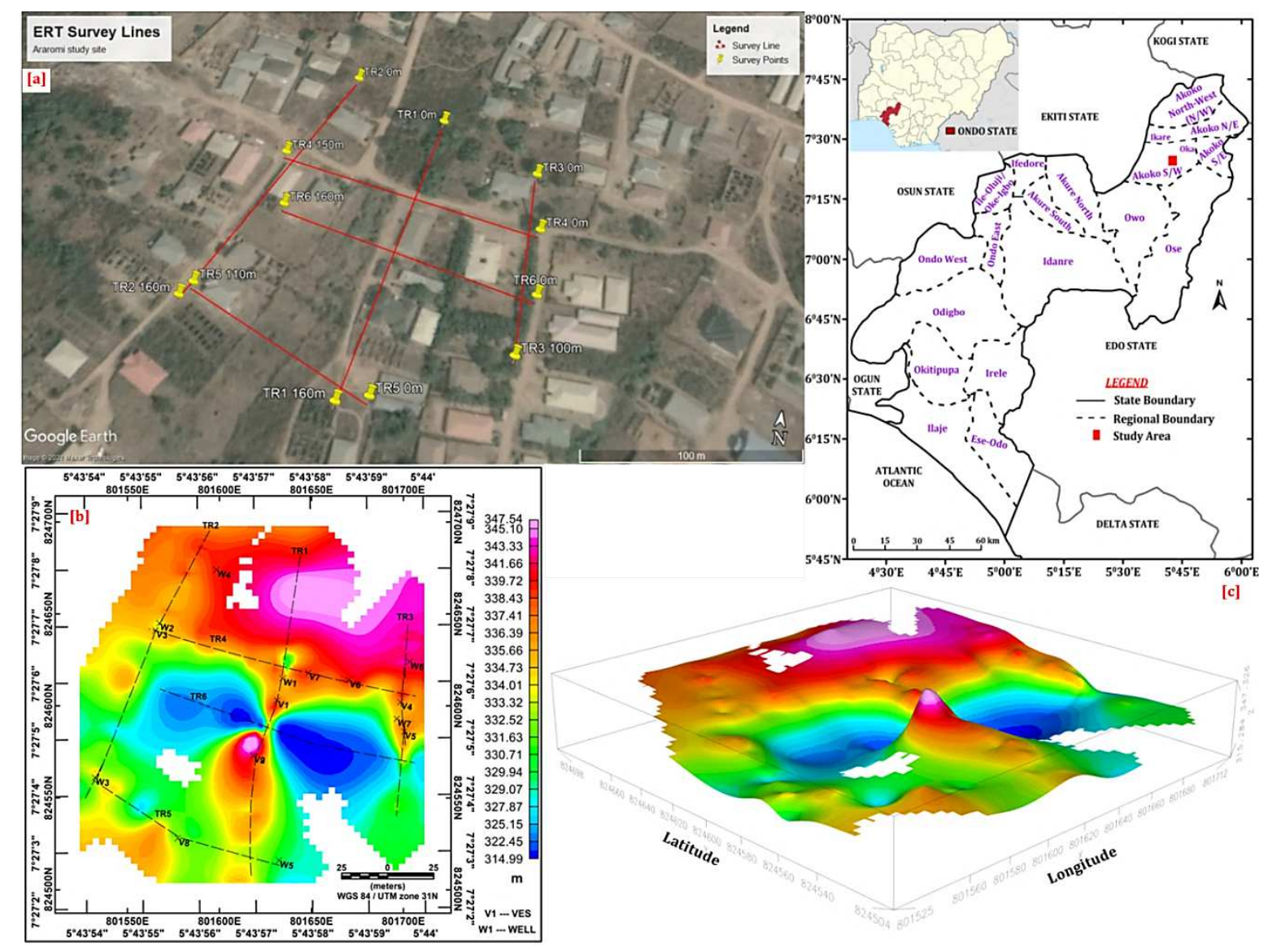

Figure 2. (a) Aerial map showing the data acquisition and all the geophysical traverses, (b)

674 elevation map showing all the VES survey station points and existing hand-dug wells in the 675 study area, and (c) the 3-D topographical view of the study area. 

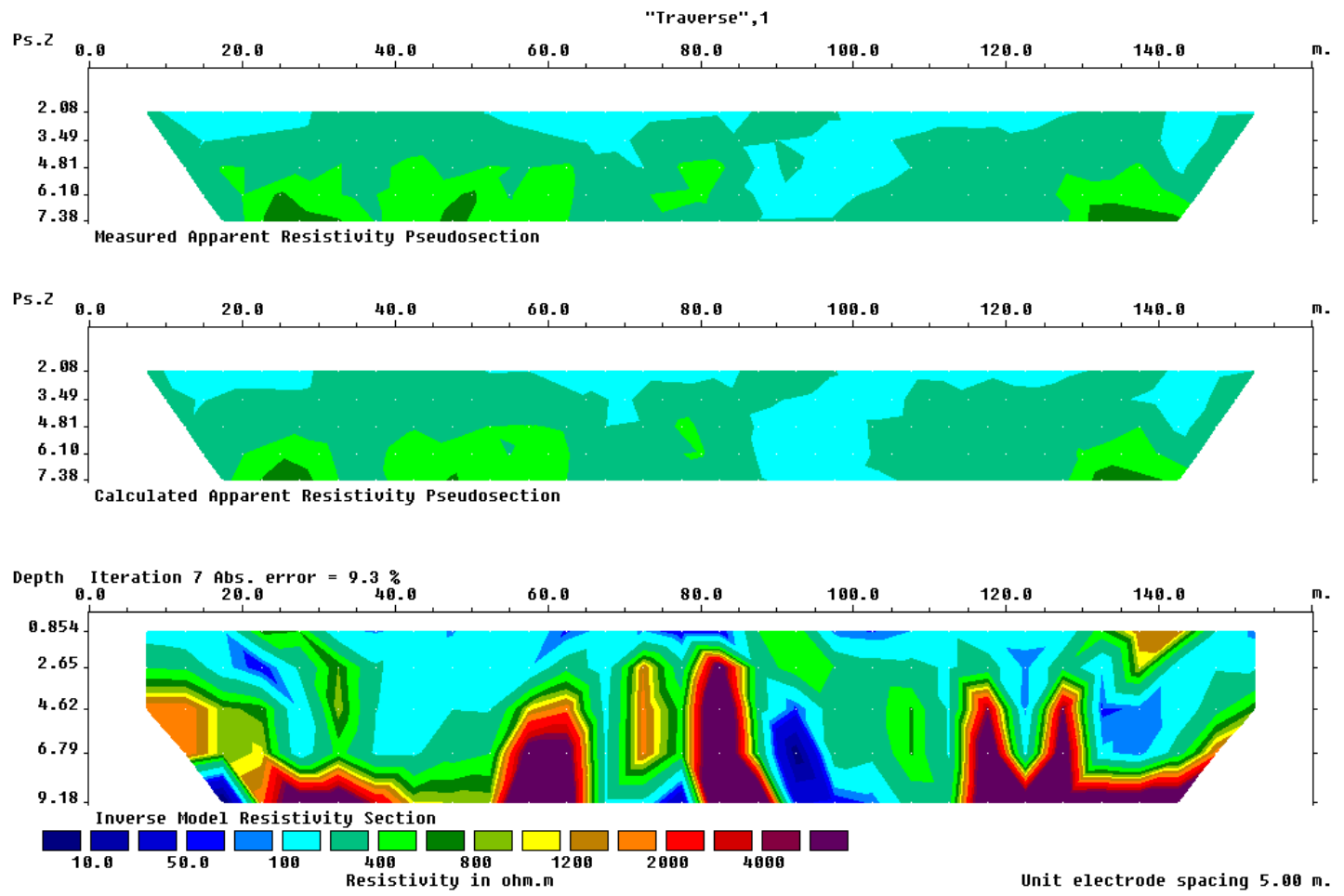

Figure 3. Composite results of the 2-D ERT inversion beneath TR1. 

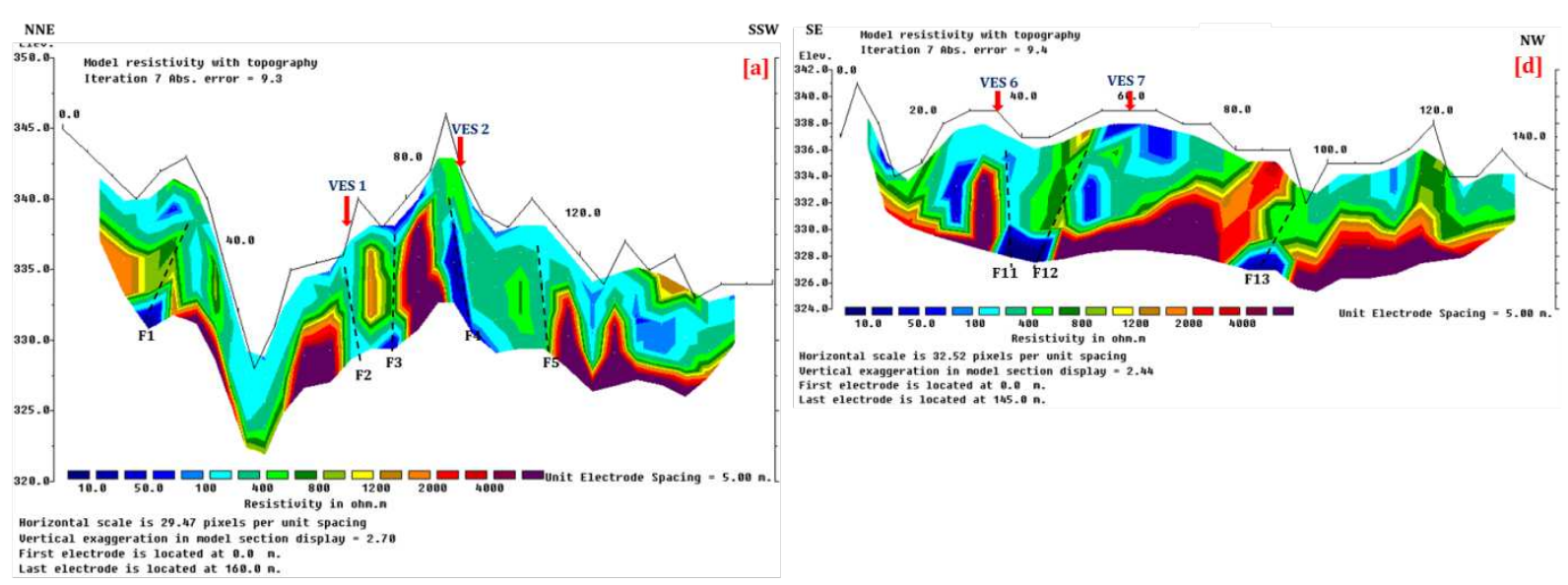

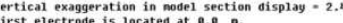

last electrode is located at $145.0 \mathrm{n}$.

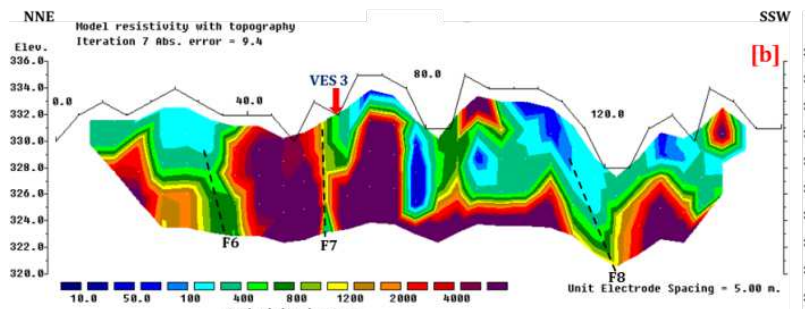

SE
Sodel resistivity with topography
tteration 7 Abs. error $=9.7$

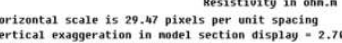

First electrode is located at 0.9 .9 .
Last electrode is located at $160.0 \mathrm{n}$

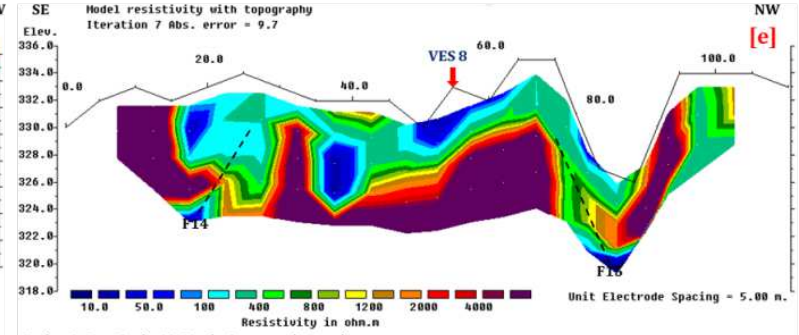

NNE Model resistivity vith topograph

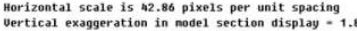
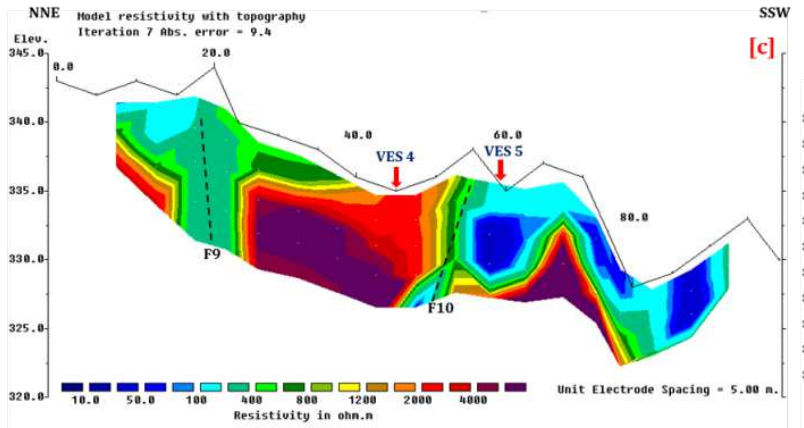

Horizontal scale is 47.15 pixels per unit spacing

First electrode is located at $0.0 \mathrm{n}$.
Last electrode is $10 \mathrm{coted}$ at $1980.8 \mathrm{n}$.

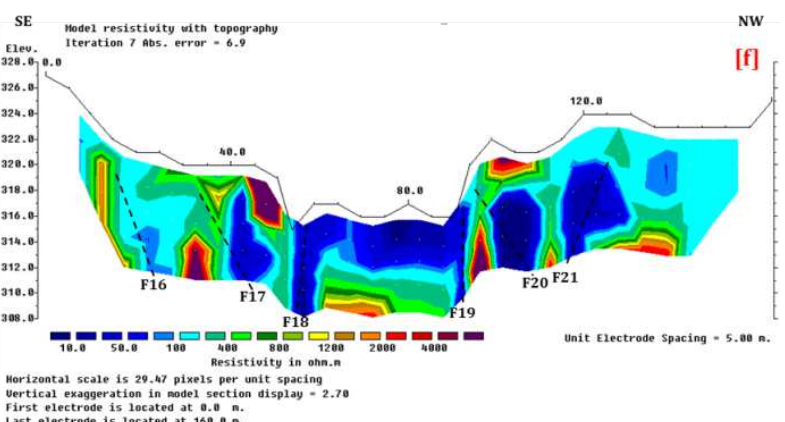

680

Figure 4. Inverted model resistivity section beneath the geoelectric surveyed traverses. 

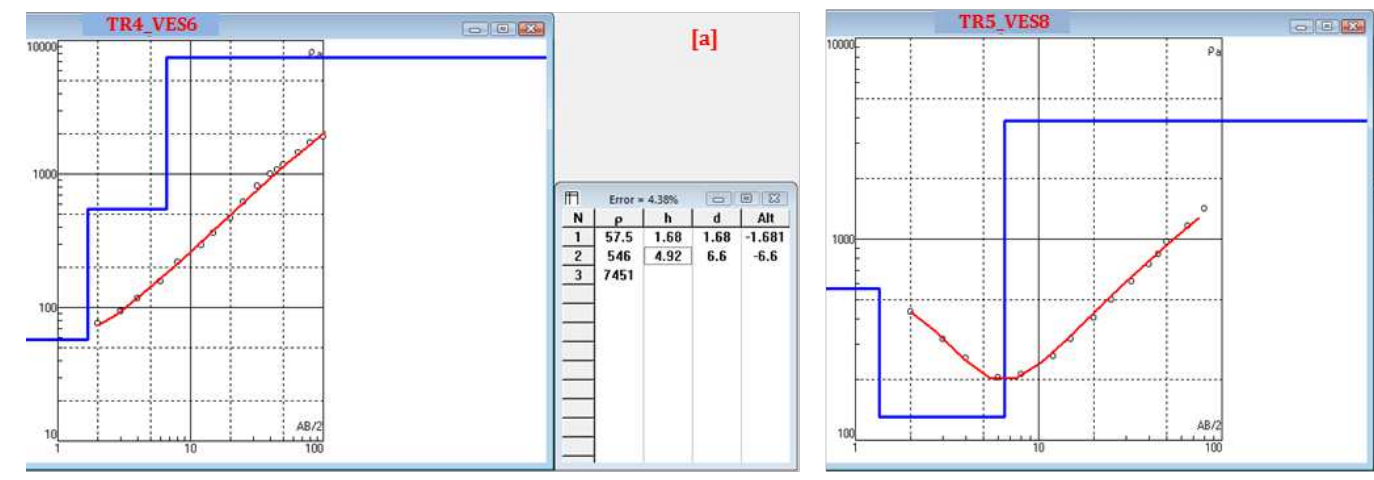

[c]
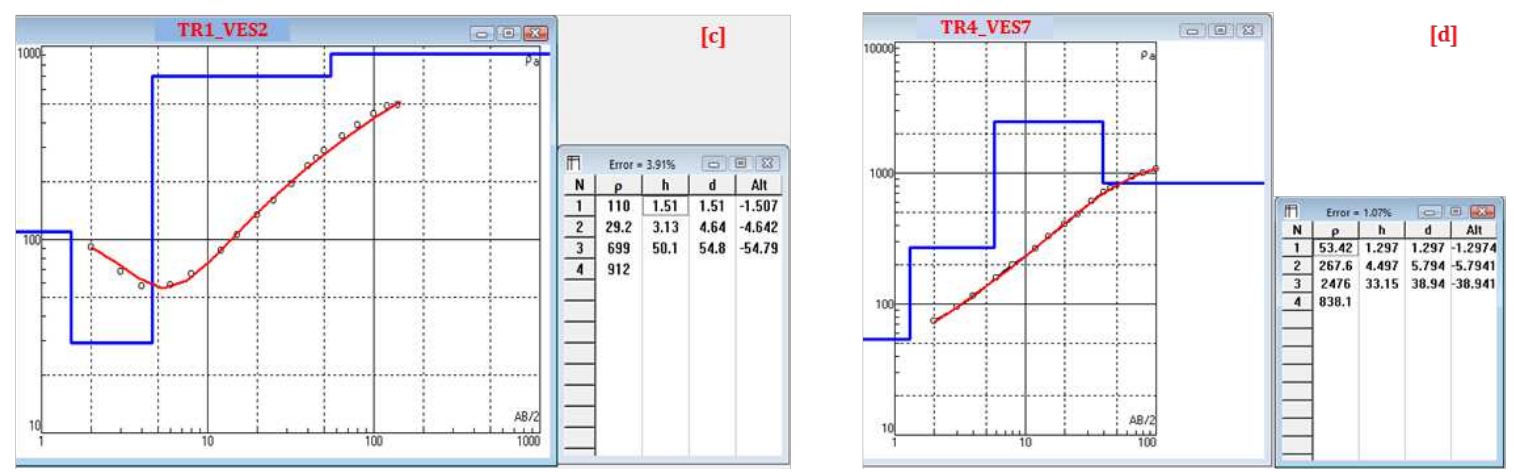

682 Figure 5. Typical iterated VES curve types generated for the study area include (a) A type, (b) 683 H type, (c) HA type, and (d) AK type. 